\title{
PENENTUAN AWAL WAKTU SHALAT SUBUH MENURUT KEMENTERIAN AGAMA DAN ALIRAN SALAFI
}

\author{
Moh. Afif Amrulloh \\ UIN Maulana Malik Ibrahim Malang \\ Email: syariah@uin-malang.ac.id
}

\begin{abstract}
Abstrak
This research studied obout the way of determining time of subuh praying. The method used is qualitative approach, that are editing, clasification, and verification. The result of this research, the is difference perspective between the BHR Department of Religious early and Salafi stream. BHR Religion Department considers this problem is the problem Ijtihadiyah. Department of Religious BHR depart from the perspective of astronomy, while the Salafi depart from the perspective of syar'i. This different is natural thing, because it departed from the different standpoint. Interpretation of Qur'an verses and Prophetic traditions, particularly related to the true dawn. There is also the different understanding of astronomical twilight; BHR Department of Religious regard astronomical twilight as fajar shadiq, while the Salafis regard as the fajar kadzib.

Penelitian ini mengkaji tentang penentuan awal waktu shalat subuh. Dengan menggunakan pendekatan kualitatif, penelitian menempuh beberapa langkah, yaitu; pengeditan, klasifikasi dan verifikasi. Kesimpulan yang diperoleh penelitian ini adalah; terdapat perbedaan perspektif dalam penentuan awal subuh antara BHR Depag dan Aliran Salafi. BHR Departemen Agama menganggap masalah ini adalah masalah ijtihadiyah. BHR Depag berangkat dari sudut pandang astronomi, sedangkan Salafi berangkat dari sudut pandang syar'i. Perbedaan ini menjadi hal yang wajar karena berangkat dari sudut pandang yang berbeda. Interpretasi terhadap ayat al-Qur'an dan hadis Nabi saw khususnya yang berkaitan dengan fajar shadiq. Begitu juga berkaitan dengan pengertian astronomical twilight yang berbeda; BHR Depag menganggap astronomical twilight sebagai fajar shadiq, sedangkan Salafi menganggapnya sebagai fajar kadzib.
\end{abstract}

Kata kunci : Shadiq, Astronomical Twilight, Badan Hisab Rukyat, Aliran Salafi

Waktu sholat subuh di Indonesia didasarkan paradigma fajar sadik terjadi apabila matahari berada pada ketinggian $-20^{\circ}$. Paradigma ini dikembangkan dan dipelopori oleh pemerintah, dalam hal ini Departemen Agama RI (sekarang diganti dengan nama Kementeriaan Agama RI).

Akhir-akhir ini, perbedaan pendapat seputar penentuan awal waktu subuh ini lebih terasa dan mencuat ke permukaan, setelah kaum salafi menyampaikan pernyataan bahwa waktu subuh di Indonesia lebih awal 15 - 23 menit. Bahkan dalam salah satu artikel yang dimuat dalam sebuah majalah Qiblati menilai bahwa penetapan awal waktu subuh di Indonesia sebagai amalan bid'ah yang tersesat. ${ }^{1}$

Perbedaan pendapat ini juga mengilhami Majlis Tarjih dan Tajdid Muhammadiyah untuk membuat

1 Majalah Qiblati,( Edisi 9 Tahun VI), h. 33-36 pernyataan yang sangat krusial bagi masyarakat muslim Indonesia. Menurut Ketua Majlis Tarjih dan Tajdid Muhammadiyah (MTT) Syamsul Anwar, awal waktu shalat subuh di Indonesia terlalu pagi $10-15$ menit. Azan subuh dianggap terlalu dini (pagi) untuk dikumandangkan. Parameternya adalah azan subuh di Indonesia dikumandangkan saat matahari berada $20^{\circ}$ di bawah ufuk (titik matahari mulai terlihat). Beliau lantas membandingkan waktu azan subuh di Maroko dan Mesir. Dua negara di Benua Afrika yang mayoritas berwarga muslim itu menetapkan waktu subuh itu pada saat matahari berada di titik masingmasing $18^{\circ}$ dan $19,5^{\circ}$ di bawah ufuk.

Sesuai hukum Islam, waktu subuh adalah di antara $20^{\circ}$ sebelum ufuk hingga $0^{\circ}$ ufuk. ${ }^{2}$ Fenomena yang dipaparkan di atas dapat dilihat dari beberapa

2 Jawa Pos, (24 Maret 2010), h. 16 

perspektif. Dari perspektif sosial keagamaan, hal ini sungguh sangat meresahkan masyarakat muslim Indonesia yang selama ini melaksanakan shalat subuh pada awal waktu. Akibatnya, shalat subuh yang selama ini mereka kerjakan tidak sah dan mereka harus mengqadha' shalat subuh seumur hidup mereka.

Dari sisi lain, hal itu merupakan "berkah" bagi masyarakat muslim Indonesia yang sering atau bahkan selalu bangun kesiangan. Namun dari perspektif ilmiah, khususnya kajian falakiyah, fenomena ini menarik untuk diteliti dan dikaji ulang. Mengingat pentingnya mengetahui masuknya waktu shalat itu merupakan salah satu dari syarat sah shalat, maka peneliti mencoba untuk mencari kebenaran ilmiah tentang fajar shadiq sebagai pedoman awal waktu shalat subuh dalam penelitian ini. Oleh karena itu, untuk mempermudah arah pembahasan, maka penelitian ini diberi judul "Penentuan Awal Waktu Shalat Subuh menurut Badan Hisab Rukyat Kementerian Agama dan Aliran Salafi”.

\section{Metode}

Penelitian ini termasuk penelitian kualitatif. Penelitian kualitatif adalah penelitian yang bermaksud untuk memahami fenomena tentang apa yang dialami oleh subyek penelitian secara holistik, dan dengan cara deskripsi dalam bentuk kata-kata dan bahasa, pada suatu konteks khusus yang alamiah dan dengan memanfaatkan berbagai metode ilmiah ${ }^{3}$.

Dalam penelitian ini, fenomena yang penting untuk diteliti adalah fenomena tentang shalat subuh yang dianggap "terlalu pagi" untuk mayoritas negaranegara muslim, tak terkecuali Indonesia. Berdasarkan tempat penelitiannya, maka penelitian ini termasuk penelitian kepustakaan (library research); yaitu penelitian yang dilaksanakan dengan menggunakan literatur (kepustakaan), baik berupa buku, catatan, maupun laporan hasil penelitian dari peneliti terdahulu.

Untuk mempermudah memahami data yang diperoleh secara baik, rapi, dan sistematis, maka pengolahan data dengan beberapa tahapan menjadi sangat penting dan signifikan. Tahapan-tahapan pengolahan data dalam penelitian ini adalah: ${ }^{4}$ (a) Pengeditan, tahap pertama dilakukan untuk meneliti kembali data-data yang telah diperoleh terutama dari kelengkapannya, kejelasan makna, kesesuaian serta relevansinya dengan kelompok data yang lain, dengan

\footnotetext{
Lexy J. Moleong, Metodologi Penelitian Kualitatif, (Bandung : PT Remaja Rosdakarya, 2007), h. 6.

4 M. Amin Abdullah, dkk., Metodologi Penelitian Agama: Pendekatan Multidisipliner, (Yogyakarta: Kurnia Kalam Semesta, 2006), h. 223.
}

tujuan apakah data-data tersebut sudah mencukupi untuk memecahkan permasalahan yang diteliti, dan untuk mengurangi kesalahan dan kekurangan data dalam penelitian serta untuk meningkatkan kualitas data. (b) Tahapan kedua adalah klasifikasi, klasifikasi adalah mereduksi data yang ada dengan cara menyusun dan mengelompokkan data yang diperoleh ke dalam pola tertentu atau permasalahan tertentu untuk mempermudah pembacaan dan pembahasan sesuai dengan kebutuhan penelitian. (c) Tahap ketiga adalah verifikasi, verifikasi data adalah pembuktian kebenaran data untuk menjamin validitas data yang telah terkumpul. Verifikasi ini dilakukan dengan cara mengecek kembali data-data yang sudah terkumpul dari beberapa literatur kitab klasik, literatur dari Badan Hisab dan Rukyat Departemen Agama, literatur dari aliran Salafi dan artikel-artikel koran dan internet yang sudah terkumpul yang berhubungan dengan bahasan.

Setelah semua data terkumpul, maka data dianalisa untuk mendapatkan konklusi. Analisa data ialah proses penyederhanaan data ke dalam bentuk yang muda dibaca dan diinterpretasikan. Metode analisa data yang digunakan adalah deskriptif. Analisis dengan menggunakan deskriptif adalah menggambarkan fenomena-fenomena yang ada, baik fenomena yang bersifat alamiah ataupun rekayasa manusia. $^{5}$

\section{Hasil Dan Pembahasan}

\section{Hasil}

Sepanjang penelusuran terhadap "kitab-kitab kuning” yang berkaitan dengan waktu-waktu shalat ditemukan bahwa teks-teks yang dijadikan landasan dalam menetapkan awal waktu shalat bersifat interpretatif. Sebagai implikasinya muncul perbedaan dalam menetapkan awal waktu shalat. Kelompok pertama berpandangan bahwa awal waktu shalat ada tiga. Sementara itu, kelompok kedua menyebutkan bahwa awal waktu shalat ada lima ${ }^{6}$.

Waktu-waktu shalat fardlu dijelaskan oleh Nabi Muhammad dalam hadis-hadis beliau secara detail, penjelasannya sebagai berikut: (1) Waktu dzuhur Imam Taqiyuddin Abi Bakar Muhammad Al Husaini dalam kitab Kifayatul Akhyar fi Halli Gayatil Ikhtisar, yang diterjemahkan oleh KH. Syarifuddin Anwar dan KH. Misbah Musthafa, menyatakan:

\footnotetext{
5 Nana Syaodih Sukmadinata, Metode Penelitian Pendidikan, (Jakarta, PT Remaja Rosda Karya, 2006), h. 72.

6 Susiknan Azhari, artikel Awal Waktu Shalat Perspektif Syar'i dan Sains, Diposting oleh : admin Pada 23 Maret 2009 diakses pada tanggal 18 April 2010.
} 


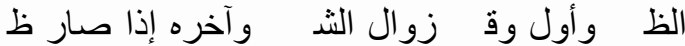

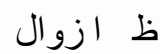

"Permulaan waktu Dhuhur adalah sejak tergelincirnya matahari. Dan akhir waktu Dzuhur adalah jika bayang-bayang suatu benda telah sepadan dengan benda itu selain bayang-bayang yang telah ada sejak matahari tergelincir (istiwak). ${ }^{7}$

Yang dimaksud zawal al-syamsi (tergelincirnya matahari) ialah apa yang tampak oleh kita, dan bukan yang berlaku dalam kenyataan. Sebab yang biasa terjadi di banyak negara, kalau matahari tepat berada di tengah-tengah langit, yakni pada waktu istiwak, orang masih melihat sisa-sisa bayangan suatu benda. Panjangnya bayangan itu berbeda-beda menurut derajat tempat dan pembagian musim. Jika matahari telah tergelincir ke arah barat, maka akan timbul bayangbayang baru di sisi Timur.

Timbulnya bayang-bayang ini, di daerah yang tiang-tiangnya tidak memiliki bayangan seperti di Mekah dan Shan'a (Yaman), pertanda tergelincirnya matahari yang berarti waktu dzuhur telah masuk. Tambahan bayang-bayang, bagi daerah yang tiangtiangnya memiliki bayangan, itulah yang dikatakan zawal (tergelincirnya matahari) yang menjadi tanda masuknya waktu shalat dzuhur. Kemudian apabila bayang-bayang itu telah menjadi sama dengan panjang benda, selain bayang-bayang zawal pada waktu istiwak, maka itu dinamakan akhir waktu dzuhur. $^{8}$

Imam Nawawi mengatakan: "Para sahabat kami mengatakan, tergelincirnya matahari adalah condongnya matahari dari pertengahan langit di waktu siang. Adapun tandanya adalah dengan bertambahnya bayangan setelah sebelumnya sempat berkurang. Hal itu dikarenakan bayangan seseorang di waktu pagi memanjang dan semakin pendek setiap kali matahari naik. Pada pertengahan bayangan itu berhenti, dan ketika matahari mulai tergelincir bayangan itu kembali bertambah panjang. ${ }^{9}$

Shalat dzuhur mempunyai enam waktu, yaitu: pertama, waktu fadhilah yaitu awalnya; kedua, waktu jawaz yaitu hingga tinggal sekedar dapat menyelesaikan shalat; Ketiga, waktu hurmah, yaitu akhir

\footnotetext{
7 Imam Taqiyuddin Abi Bakar Bin Muhammad Al-Husaini, Kifayatul Akhyar fi Halli Gayatul Ikhtisar diterjemahkan oleh KH. Syarifuddin Anwar dan K.H. Mishbah Musthafa dengan judul Kifayatul Akhyar (Kelengkapan Orang Saleh). (Surabaya : CV Bina Iman, 2007), h. 182.

8 Imam Taqiyuddin Abi Bakar Bin Muhammad Al-Husaini, Kifayatul., h. 182.

9 Imam Abu Zakariya bin Yahya bin Syaraf al-Nawawi al-Dimasyqi, "Raudhah al Thalibin", diterjemahkan H. Muhyiddin Mas Rida dkk, Raudhah al Thalibin, (Jakarta : Pustaka Azzam, 2007), h. 414.
}

waktu yang tidak sempat lagi menyelesaikan shalat seluruhnya dalam waktunya; dinamakan waktu itu waktu hurmah karena haram melambatkan/mengakhirkan shalat sampai waktu tidak dapat menyelesaikan shalat dalam waktunya. Keempat, waktu dharurah yaitu hilang mani' (penghalang) dari segala penghalang yang akan dalam waktu hanya tinggal sekedar mengangkat takbiratul ihram. Kelima, waktu udzur yaitu waktu ashar bagi orang musafir yang mengerjakan jamak ta'khir. Keenam, waktu ikhtiar yaitu waktu jawaz. Inilah yang disebutkan dalam kitab "Tuhfah" seperti tercantum dalam kitab "Majmu" yang dinukil dari pendapat mayoritas ulama'.

Berbeda dengan apa yang dikatakan oleh Qadhi bahwa waktu fadhilah seperempat dari panjang bendanya, sesudah itu waktu ikhtiar sampai dengan bayangan sesuatu setengah dari panjang bendanya dan sesudah itu waktu jawaz hingga akhir waktu. Syekh Ibnu hajar berkata di dalam kitabnya "Syarh Ubab" yang dipegangi yaitu pendapat yang disebutkan di dalam kitab "Majmu". ${ }^{10}$

Menurut al-Husaini memberikan batasan waktu shalat ashar sebagai berikut:

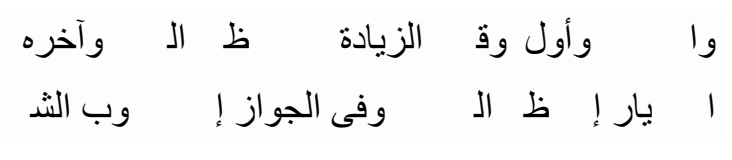

"Awal waktu ashar adalah bertambahnya bayang-bayang suatu benda sama dengan panjang benda tersebut. Dan akhir waktu ashar adalah tenggelamnya matahari"."

Jika bayang-bayang suatu benda telah sepadan dengan panjang benda, maka hal tersebut yang dikatakan akhir waktu dzuhur dan permulaan waktu ashar (menurut hadis Nabi). Namun begitu pastilah ada tambahan bayang-bayang walaupun sedikit. Karena boleh dikatakan bahwa keluarnya waktu dzuhur itu tidak mungkin dapat diketahui jika tidak ada tambahannya. Apabila bayang-bayang itu telah menjadi dua kali lipat, maka keluarlah waktu ikhtiar.

Dikatakan waktu ikhtiar karena sesuatu yang dipilih itu tentulah qaul yang rajih. Ada yang mengatakan, karena Malaikat Jibril memilih waktu ikhtiar itu. Akhir waktu ashar dalam waktu ikhtiar (pilihan), yaitu hingga bayang-bayang benda itu dua kali lipat. Akhir waktunya di dalam waktu jawaz (harus) ialah

10 Syekh Muhammad Arsyad al-Banjari, "Sabilul Muhtadin", diterjemahkan Drs. H.M. Asywadie Syukur Lc, Sabilul Muhtadin Jilid 1, (Surabaya: PT Bina Ilmu, 2005), h. 312-313.

11 Imam Taqiyuddin Abi Bakar Bin Muhammad Al-Husaini, Kifayatul., h. 82. 
hingga terbenamnya matahari. ${ }^{12}$ Perlu diketahui bahwa shalat ashar itu mempunyai empat waktu. ${ }^{13}$ Pertama, waktu fadhilah (waktu afdhal), atau utama, yaitu ketika bayang-bayang menyamai bendanya. Kedua, waktu jawaz bila karahah (harus tidak makruh), yaitu sejak bayang-bayang dua kali lipat dari bendanya hingga matahari tampak kekuningkuningan. Ketiga, waktu jawaz makruh (harus yang makruh), yakni makruh mengakhirkan shalat sampai waktu jawaz karahah ini. Yaitu sejak matahari tampak kekuning-kuningan hingga sesaat sebelum matahari terbenam. Keempat, waktu tahrim (haram), yaitu mengakhirkan shalat hingga tidak cukup waktu untuk menyelesaikan shalat. Walaupun kita katakan shalatnya termasuk shalat $a d a^{\prime}$ (tunai). Sedangkan Imam Nawawi dalam Raudhatut Thalibin membagi waktu ashar empat waktu. ${ }^{14}$ Pertama, waktu yang penuh keutamaan (awalnya). Kedua, waktu memilih hingga bayangan sesuatu sama dengannya. Ketiga, waktu setelahnya adalah waktu jawaz (boleh) tidak makruh hingga matahari mulai memerah. Keempat, dari mulai memerahnya matahari hingga waktu tenggelamnya, yaitu waktu yang makruh, sehingga makruh hukumnya menunda shalat hingga waktu ini.

Untuk waktu maghrib, para fuqaha' memberikan batasan yang sangat mudah. Misalnya Imam Nawawi memberikan batasan "awal waktu maghrib adalah terbenamnya matahari dan akhir waktu maghrib adalah hilangnya mega (cahaya) merah." Adapun yang dianggap sah adalah sejak tenggelamnya lingkaran matahari dan ini bisa terlihat di padang pasir. Sedangkan di tengah pemukiman, atau di tempat yang terhalang oleh gunung, maka waktunya dapat diketahui dengan tidak tampak sinarnya di dinding, dan disambut kegelapan dari arah timur. ${ }^{15}$

Waktu maghrib berakhir ketika mega merah terbenam. Dalam hal ini, Imam Syafi'i mempunyai dua pendapat (qaul). Menurut qaul jadid yang adzhar, waktu maghrib keluar dengan perkiraan waktu yang cukup untuk bersuci, menutup aurat, azan, iqamat dan shalat dua rakaat. Dalam perkara ini yang diperhitungkan adalah yang sedang dan sederhana. Qaul qadim mengatakan: waktu maghrib tidak keluar hingga terbenamnya mega merah. Sebab sabda Nabi saw :

\footnotetext{
12 Imam Taqiyuddin Abi Bakar Bin Muhammad Al-Husaini, Kifayatul., h. 182-183.

13 Imam Taqiyuddin Abi Bakar Bin Muhammad Al-Husaini, Kifayatul., h. 182-183.

14 Al-Nawawi al-Dimasyqi, Raudhah al Thalibin, h. 415

15 Al-Nawawi al-Dimasyqi, Raudhah al Thalibin, h. 415.
}

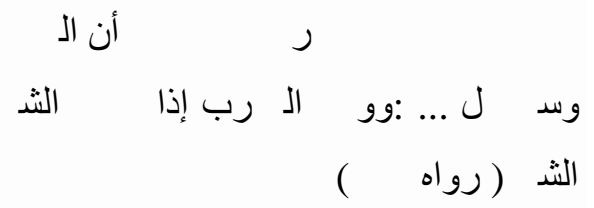

"Waktu maghrib ialah ketika matahari terbenam selama mega merah belum lenyap" (Riwayat Muslim).

Imam Rafi'i berkata: sekelompok ashhab alSyafi'i (Para sahabat Imam Syafi'i) masih memilih qaul qadim ini dan mentarjihkannya. Imam Nawawi berkata: Banyak hadis-hadis shahih yang menerangkan seperti apa yang dikatakan oleh Imam Syafi'i di dalam qaul qadimnya, dan menta'wili sebagian hadis-hadis yang lain itu sulit. Oleh karena itu, qaul qadim inilah yang benar. Di antara para ulama' madzab yang memilih qaul qadim ialah Ibnu Khuzaimah, al-Khaththabi, al-Baihaqi, Imam Ghazali di dalam Ihya' Ulumuddin, dan al-Baghawi di dalam kitab al-Tadzhib. ${ }^{16}$

Waktu maghrib terbagi kepada enam waktu, yaitu: ${ }^{17}$ Pertama, waktu fadhilah yaitu awal waktunya. Kedua, waktu ikhtiar yaitu waktu fadhilah itu sendiri. Ketiga, waktu jawaz dengan karahah yaitu sesudah waktu fadhilah sampai kadar waktu menyelesaikan shalat. Dan disebutkan dalam di dalam kitab "Tuhfah" bahwa makruh melambatkan atau mengakhirkan shalat maghrib dari waktu fadhilah menurut qaul qadim dan jadid. Maka berdasarkan dua qaul ini bahwa waktu maghrib tidak tergambar waktu jawaz dengan tiada karahah. Maka dipahami dari perkataan ini sesudah waktu fadhilah. Keempat, waktu hurmah. Kelima, waktu darurat. Keenam, waktu udzur yaitu waktu isya' bagi orang musafir yang mengerjakan jamak ta'khir. Waktu isya' batasan waktu shalat ashar, menurut Imam Taqiyuddin Abi Bakar Muhammad Al Husaini :

$$
\begin{aligned}
& \text { وا }
\end{aligned}
$$

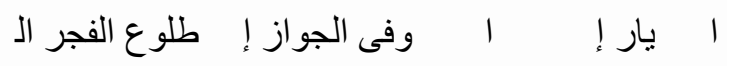

Permulaan waktu isya' ialah ketika mega merah telah lenyap. Dan akhir waktunya di dalam waktu ikhtiar, hingga sepertiga malam. Dan akhir waktunya di dalam waktu jawaz hingga munculnya fajar yang kedua. $^{18}$

\footnotetext{
16 Imam Taqiyuddin Abi Bakar Bin Muhammad Al-Husaini, Kifayatul., h. 185.

17 Al-Banjari, h. 315-316.

18 Imam Taqiyuddin Abi Bakar Bin Muhammad Al-Husaini, Kifayatul., h. 185 ,
} 
Masuknya waktu isya' bersama dengan hilangnya mega merah menurut beberapa hadis. Ibnu Rif'ah mengatakan ketetapan tersebut berdasarkan ijmak ulama'. Waktu ikhtiar untuk shalat isya' yaitu sebelum lewat sepertiga malam, karena hadisnya Jibril a.s. Di dalam satu qaul dikatakan bahwa waktu ikhtiar untuk shalat isya' itu hingga lewat separuh malam. Karena sabda Nabi Muhammad saw.

$$
\text { وسد ل ل.... :وو }
$$

"Dari Abdullah ibn Umar r.a. bahwa Nabi saw bersabda: waktu shalat isya' itu hingga separuh malam". H.R. Muslim.

Imam Nawawi berkata di dalam Syarah alMuhadzdzab: apa yang dikatakan oleh sebagian ulama' cenderung untuk mentarjihkan qaul ini. Imam Nawawi menerangkan di dalam Syarah Muslim dalam mentarjihkan qaul ini, beliau berkata: Qaul ini adalah qaul yang ashah. Adapun waktu jawaz untuk shalat isya' hingga munculnya fajar kedua, menurut keterangan dari beberapa hadis Rasulullah. Syaikh Abu Hamid menerangkan bahwa shalat isya' mempunyai waktu karahah (makruh), yaitu antara dua fajar, fajar shadiq dan fajar kadzib. ${ }^{19}$

Imam Syafi'i mengatakan bahwa al-syafaq adalah warna merah di langit. Kemudian terbenamnya warna merah itu jelas di kebanyakan tempat. Sedangkan orang-orang yang bertempat tinggal di suatu tempat yang malamnya pendek dan tidak melihat terbenamnya warna merah, maka hendaknya dia melaksanakan shalat isya' apabila diperkirakan telah berlalu waktu hilangnya warna merah di langit di negeri terdekat. ${ }^{20}$ Sedangkan waktu pilihan untuk shalat isya', maka waktunya membentang hingga sepertiga malam menurut pendapat yang azhar dan hingga separuhnya menurut pendapat yang kedua. Akan tetapi waktu pelaksanaan shalat isya' masih diperbolehkan hingga terbit fajar kedua (fajar shadiq) menurut pendapat yang sahih.

Al-Ashthakhri mengatakan, "Waktu isya' keluar dengan keluarnya waktu pilihan". ${ }^{21}$ Waktu imsak Imsak adalah waktu tertentu sebelum subuh, saat di mana biasanya kaum muslimin mulai berpuasa. Sebetulnya, sesuai dengan al-Qur'an Surat al-Baqarah

\footnotetext{
19 Imam Taqiyuddin Abi Bakar Bin Muhammad Al-Husaini, Kifayatul., h. 185.

20 Imam Nawawi al-Dimasyqiy, Raudhah al Thalibin, h. 418.

21 Imam Nawawi al-Dimasyqiy, Raudhah., h. 418.
}

187, puasa dimulai sejak terbit fajar sebagaimana dimulainya waktu shalat subuh. Karena itu, puasa yang dimulai sejak imsak adalah merupakan ihtiyati, sesuai dengan hadis Nabi yang diriwayatkan Bukhari dan Muslim dari Anas. Namun demikian ada juga yang menganggap kewajiban puasa dimulai sejak imsak seperti pendapat Imam Malik ${ }^{22}$. Hadis Nabi saw yang diriwayatkan oleh Bukhari dan Muslim dari Anas tentang Imsak adalah sebagai berikut:

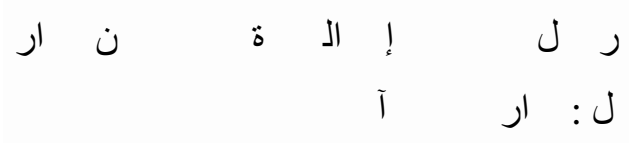

"Kami sahur bersama Nabi Muhammad saw, kemudian kami melakukan shalat (subuh)" "Saya berkata: "Berapa lama ukuran antara sahur dan subuh?" Nabi bersabda : "seukuran membaca 50 ayat al-Qur'an!"

Para ulama' berbeda pendapat tentang lama membaca 50 ayat tersebut. Dalam kitab Nailul Authar disebutkan seukuran melakukan wudhu'. Dalam kitab al-Mukhtashar al-Muhadzab disebutkan bahwa waktu imsak itu sekitar 12 menit sebelum waktu terbitnya fajar. Dalam al-Mukhtashar juga disebutkan ihtiyathi-ihtiyathi untuk shalat-shalat wajib, yaitu 2 menit untuk ashar dan isya', 3 menit untuk maghrib, 4 menit untuk dzuhur dan 5 menit untuk subuh. Dalam kitab Khulashah al-Wafiyah (Syekh Zubair Umar al Jilani) disebutkan bahwa imsak seukuran 50 ayat yang pertengahan secara murattal adalah sekitar 7 atau 8 menit. Sedangkan H. Saadoedin Jambek biasa mempergunakan 10 menit sebelum subuh. Dalam praktek ada yang menentukan lebih 10 menit bahkan 20 menit. $^{23}$

Pendapat terakhir ini yang sering digunakan Kementerian Agama atau di berbagai program jadwal waktu shalat. Jika kita perhatikan antara imsak dengan data ihtiyath yang biasa dipergunakan untuk menentukan waktu-waktu shalat, walaupun kedua masalah itu pada hakekatnya sama yaitu untuk "hati-hati/pengaman", namun ada sedikit perbedaan. Ukuran imsak jelas dasarnya yaitu ukuran membaca 50 ayat seperti pada hadis di atas (walaupun berapa menit lamanya tidak ada ketentuan pasti). Imsak juga semata-mata hanya alasan syara' bukan alasan teknis hisab. Sedangkan ihtiyath lebih banyak disebabkan karena keperluan teknis hisab, seperti adanya

\footnotetext{
22 Departemen Agama RI, al-Qur'an dan Terjemahnya: Juz 1 - Juz 30 (Jakarta: Yayasan Penyelenggara Penterjemah Al-Qur'an, 1989), h. 49.

23 Departemen Agama RI, Pedoman Penentuan Waktu Shalat Sepanjang Masa, (Jakarta, 1994), h. 50.
} 
pembulatan, adanya pemindahan markaz dan lainlain. ${ }^{24}$ Permulaan waktu subuh ialah munculnya fajar. Akhir waktunya di dalam waktu ikhtiar ialah hingga remang-remang pagi. Akhir waktunya di dalam waktu jawaz ialah hingga munculnya matahari. ${ }^{25}$

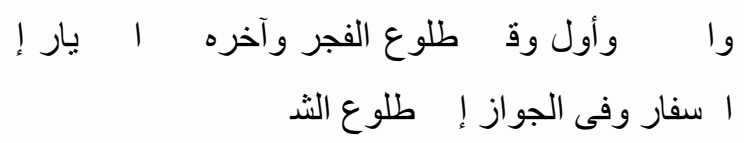

Yang dimaksud dengan permulaan waktu subuh ialah munculnya fajar. Fajar di sini dimaksudkan adalah fajar shadiq. Fajar shadiq ialah fajar yang terangnya menyebar dan melintang di ufuk timur. Fajar ini ialah fajar yang kedua. Adapun fajar pertama tidak merupakan permulaan masuknya waktu subuh. Fajar itu warnanya abu-abu, bentuknya memanjang ke atas. Fajar ini juga dikatakan sebagai fajar kadzib, karena dia bersinar lalu menghitam lagi. Waktu ihtiyar untuk shalat subuh yaitu hingga remang-remang pagi, karena hadis Jibril. Waktu jawaz berlangsung hingga munculnya matahari, karena sabda Rasulullah saw :

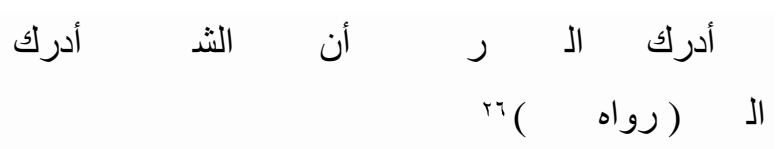

"Barang siapa menemukan satu rakaat dari shalat subuhnya sebelum terbit matahari, orang tersebut berarti telah menemukan shalat subuh" (HR Muslim).

Perlu diketahui bahwa waktu jawaz yang tidak makruh berlangsung hingga muncul kemerah-merahan. Maka apabila kemerah-merahan itu telah muncul, datanglah waktu yang makruh hingga terbit matahari. Demikian itu apabila tidak ada udzur. ${ }^{27}$ Waktu terbit (Thulu') merupakan waktu berakhirnya waktu shalat subuh yang ditandai dengan posisi matahari berada pada ketinggian matahari -1 derajat di sebelah timur. ${ }^{28}$

Allah swt berfirman :

$$
\text { وا شراق }
$$

Abdullah bin Abbas menafsirkan kata al-isyraq dengan shalat dhuha. Waktu pelaksanaan shalat dhuha menurut Imam Rafi'i adalah ketika matahari

\footnotetext{
24 Departemen Agama RI, Pedoman., h. 50.

25 Imam Taqiyuddin Abi Bakar Bin Muhammad Al-Husaini, Kifayatul., h. 186.

26 Al-Hafidh bin Hajar al-'Asqalaniy, Bulughul al-Maram min Adillah alAhkam, (Syirkah Al-Nur Asia, tt), h. 43.

27 Imam Taqiyuddin Abi Bakar Bin Muhammad Al-Husaini, Kifayatul., h. 186.

28 Murtadho, Ilmu Falak Praktis (Malang: UIN Press, 2008), h. 187.
}

naik setinggi tombak sampai waktu istiwak. Pendapat tersebut diikuti oleh al-Nawawi al-Dimasyqi sebagaimana tercantum dalam Syarh al-Muhadzab. Ibnu Rif'ah Imam al Mawardi berkata; "waktu yang tepat untuk melaksanakan shalat dhuha adalah ketika lewat $1 / 4$ waktu siang. Hal ini menurut Imam al-Ghazali dimaksudkan agar seorang hamba itu selama $1 / 4$ dari waktu siang itu tidak kosong/sepi untuk beribadah kepada Allah swt. ${ }^{29}$

Dalam wacana fiqh, awal waktu dhuha dimulai sejak matahari naik "setinggi tombak" (bi qadr alramh). Pengertian "setinggi tombak" tersebut diaplikasikan dalam ukuran falakiyah apabila matahari naik setinggi 4 derajat 30 derajat, yaitu kurang lebih 18 menit setelah terbit matahari. ${ }^{30}$

Dalam tata surya, matahari merupakan pusat dan penggerak anggota-anggotanya, yaitu planet-planet. Karena adanya gaya tarik menarik dari matahari (gaya gravitasi), planet-planet beredar mengelilingi matahari. Komet-komet juga datang mendekati matahari berulang kali. Jadi kehidupan ini sangat dipengaruhi oleh matahari. Hal ini sesuai dengan teori Heliosentris yang diperkenalkan oleh Copernicus, yaitu matahari sebagai pusat dari peredaran planetplanet. $^{31}$

Matahari mempunyai gerakan rotasi, yaitu gerakan berputar pada porosnya. Arah rotasinya sesuai dengan arah rotasi sebagian besar planet dan satelit, yaitu arah negatif atau berlawanan dengan arah jarum jam atau disebut juga ricktograad (yakni apabila dilihat dari utara, maka matahari berputar pada porosnya dari barat ke timur. Periode rotasi bagian equator matahari adalah 34 hari. Semakin matahari itu mendekati kutub, rotasi itu makin lambat. Rotasi matahari di sekitar kutub memakan waktu selama 27 hari.

Adanya perbedaan ini karena matahari itu berbentuk gas. Fenomena rotasi ini dapat dilihat dari adanya gerakan bintik-bintik matahari (sunspot). Bintik matahari adalah bagian permukaan matahari yang suhunya lebih rendah daripada suhu di sekitarnya, karena lebih dingin maka kelihatan lebih gelap menyerupai bintik-bintik. Dari keterangan tersebut, matahari sebagai sumber kehidupan memiliki manfaat dan fungsi yang besar bagi umat manusia. Salah satu manfaat dan fungsi matahari adalah sebagai pedoman atau pijakan dalam penentuan awal dan akhir waktu shalat bagi umat Islam.

\footnotetext{
29 Imam Taqiyuddin Abi Bakar Bin Muhammad Al-Husaini, Kifayatul., h. 195.

30 Murtadho, Ilmu., h. 187

31 Maskufa, Ilmu Falak, (Jakarta : Gaung Persada Press, 2009), h. 42.
} 
Waktu shalat berkaitan dengan peristiwa peredaran semu matahari relatif terhadap bumi. Dikatakan gerak semu, karena matahari sebenarnya tidak bergerak, melainkan bumilah yang berputar pada sumbunya dari barat ke timur sehingga terlihat matahari bergerak dari timur ke barat. Imam Nawawi alJawi memberikan catatan bahwa waktu-waktu shalat itu pada setiap daerah itu berbeda-beda menurut posisi dan ketinggian matahari di daerah-daerah tersebut.

Ada kalanya posisi matahari di suatu daerah sedang tergelincir, padahal di daerah lain justru matahari sedang terbit (thulu').

Hal ini mengindikasikan bahwa bagaimanapun juga posisi dan ketinggian matahari sangat mempengaruhi penentuan awal dan akhir waktu shalat. Adapun posisi dan ketinggian matahari untuk setiap waktu shalat subuh secara terperinci adalah sebagai berikut: waktu subuh awal subuh ditandai dengan mulai surutnya cahaya bintang-bintang di langit disebabkan oleh pengaruh sinar matahari yang datang di langit sebelah timur yang menandakan adanya perubahan dari gelap ke terang. Pada saat itu jarak zenit matahari adalah $90^{\circ}+20^{\circ}$ atau tinggi matahari pada saat itu $=$ $-20^{\circ}$. Untuk menentukan awal waktu subuh dapat dicari dengan rumus $\cos t=-\tan \gamma \tan \delta+\sin -20^{\circ}: \cos \gamma: \cos$ $\delta$, selanjutnya dilakukan koreksi waktu dan ihtiyath. ${ }^{32}$

Berdasarkan surat Departemen Agama RI Direktorat Jenderal Bimbingan Masyarakat Islam, no Dj.11.2/5/HK.03.2/1832/2009 tentang Pengkajian Ulang Penetapan Waktu Shalat Subuh bahwasanya Departemen Agama melalui Badan Hisab Rukyat sebagai wadah kajian terhadap hal-hal yang berkaitan dengan waktu shalat, arah kiblat, awal bulan qamariyah, gerhana matahari dan bulan serta hal-hal yang berhubungan dengan falak/astronomi telah melakukan pembahasan dan kajian yaitu pertemuan dan Sidang Anggota Badan Hisab Rukyat Kementerian Agama tahun 2009 M, tanggal 3-4 Agustus 2009 M/ 12-13 Sya'ban $1430 \mathrm{H}$, yang diselenggarakan oleh Ditjen Bimas Islam Kementerian Agama.

Pembahasan dan pengkajian yang berkaitan dengan fajar kidzib dan fajar shadiq dihadiri oleh Departemen Agama, Mahkaman Agung RI, Pengadilan Agama, Pakar Astronomi ITB, UIN/ IAIN, LAPAN, Planetarium, Ormas Islam dan ulama' ulama' ahli falak perorangan. Agar tidak merubah substansi dari pandangan Badan Hisab Rukyat Depag yang diwakili oleh Djamaluddin, maka peneliti memaparkan makalah yang ditujukan kepada Qiblati se-

32 Maskufa, Ilmu., h. 101-102. bagai bentuk respon terhadap permasalahan ini sesuai teks aslinya. Berikut paparan beliau:

Waktu subuh ditinjau dari dalil Syar'I dan Astronomi. ${ }^{33}$ Penentuan waktu subuh diperlukan untuk awal shaum (puasa) dan shalat. Tentang waktu awal shaum disebutkan dalam al-Qur'an:

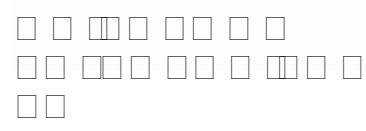

"...Makan dan minumlah hingga terang bagimu benang putih dari benang hitam, yaitu fajar" (QS al Baqarah 187).

Sedangkan tentang awal waktu subuh disebutkan di dalam hadis dari Abdullah bin Umar.

$$
\text { الثد }
$$

“... dan waktu shalat subuh sejak terbit fajar selama sebelum terbit matahari” (HR. Muslim).

Fajar yang bagaimana yang dimaksudkan tersebut? Hadis dari Jabir merincinya,

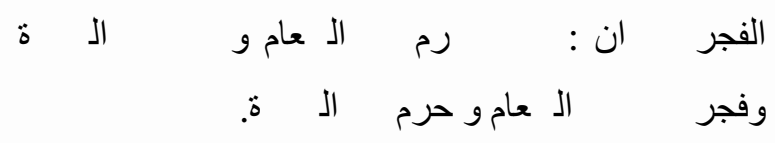

"Fajar ada dua macam, pertama yang melarang makan, tetapi membolehkan shalat, yaitu yang terbit melintang di ufuk. Lainnya, fajar yang melarang shalat (subuh), tetapi membolehkan makan, yaitu fajar seperti ekor serigala” (HR Hakim).

Dalam fikih dikenalnya sebagai fajar shadiq (benar) dan fajar kidzib (palsu). Lalu fajar shadiq seperti apakah yang dimaksud Rasulullah saw.

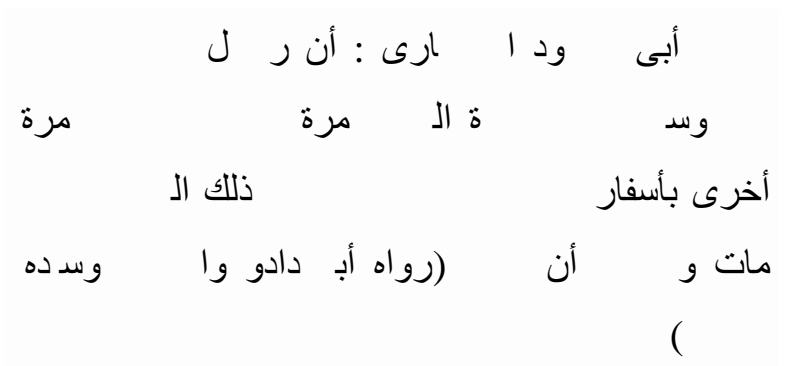

Dalam hadis dari Abu Mas'ud al-Anshari disebutkan, "Rasulullah saw shalat subuh saat kelam pada akhir malam, kemudian pada kesempatan lain ketika

\footnotetext{
33 Majalah Qiblati edisi 2 tahun V, 28-30; Syekh Mamduh Farhan al Buhairi dkk, Koreksi Awal Waktu Subuh, (Malang, Pustaka Qiblati: 2010), h. 41-44 dan 287-288.
} 
hari mulai terang. Setelah itu shalat tetap dilakukan pada waktu gelap sampai beliau wafat, tidak pernah lagi pada waktu mulai terang." (HR Abu Dawud dan Baihaqi dengan sanad yang sahih).

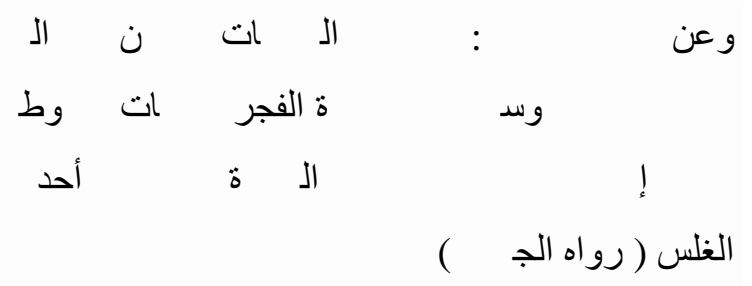

Lebih lanjut hadis dari Aisyah,"Perempuanperempuan mukmin ikut melakukan shalat fajar (subuh) bersama Nabi saw dengan menyelubungi badan mereka dengan kain. Setelah shalat mereka kembali ke rumah tanpa dikenal siapapun karena masih gelap." (HR Jama'ah).

Karena saat ini waktu-waktu shalat lebih banyak ditentukan berdasarkan jam, perlu diketahui kriteria astronomisnya yang menjelaskan fenomena fajar dalam dalil syar'i tersebut. Perlu penjelasan fenomena sesungguhnya fajar kidzib dan fajar shadiq.

Kemudian perlu batasan kuantitatif yang dapat digunakan dalam formulasi perhitungan untuk diterjemahkan dalam rumus atau algoritma program komputer. Fajar kidzib memang bukan fajar dalam pemahaman umum, yang secara astronomi disebut cahaya zodiak. Cahaya zodiak disebabkan oleh hamburan cahaya matahari oleh debu-debu antar planet yang tersebar di bidang ekliptika yang tampak di langit melintasi rangkaian zodiak (rangkaian rasi bintang yang tampaknya dilalui matahari).

Oleh karenanya fajar kidzib tampak menjulur ke atas seperti ekor serigala, yang arahnya sesuai dengan arah ekliptika. Fajar kidzib muncul sebelum fajar shadiq ketika malam masih gelap. Fajar shadiq adalah hamburan cahaya matahari oleh partikel-partikel di udara yang melingkupi bumi. Dalam bahasa al-Qur'an fenomena itu diibaratkan dengan ungkapan "terang bagimu benang putih dari benang hitam", yaitu peralihan dari gelap malam (hitam) menuju munculnya cahaya (putih).

Dalam bahasa fisika hitam bermakna tidak ada cahaya yang dipancarkan, dan putih bermakna ada cahaya yang dipancarkan. Karena sumber cahaya itu dari matahari dan penghamburnya adalah udara, maka cahaya fajar melintang di sepanjang ufuk (horison, kaki langit). Hal itu pertanda akhir malam, menjelang matahari terbit. Semakin matahari mendekati ufuk, semakin terang fajar shadiq. Jadi batasan yang bisa digunakan adalah jarak matahari di bawah ufuk. Secara astronomi, fajar (morning twilight) dibagi menjadi tiga: fajar astronomi, fajar nautika, dan fajar sipil. Fajar astronomi didefinisikan sebagai akhir malam, ketika cahaya bintang mulai meredup karena mulai munculnya hamburan cahaya matahari. Biasanya didefinisikan berdasharkan kurva cahaya, fajar astronomi ketika matahari berada sekitar $18^{\circ}$ di bawah ufuk. Fajar nautika adalah fajar yang menampakkan ufuk bagi para pelaut, pada saat matahari berada di sekitar $12^{\circ}$ di bawah ufuk. Fajar sipil adalah fajar yang mulai menampakkan benda benda di sekitar kita, pada saat matahari berada sekitar $6^{\circ}$.

Fajar apakah sebagai pembatas awal shaum dan shalat subuh? Dari hadis Aisyah disebutkan bahwa saat para perempuan mukmin pulang dari shalat subuh berjamaah bersama Nabi saw, mereka tidak dikenali karena masih gelap. Jadi, fajar shadiq bukanlah fajar sipil karena saat fajar sipil sudah cukup terang dan juga bukan fajar nautika karena seusai shalatpun masih gelap. Kalau demikian, fajar shadiq adalah fajar astronomi, saat akhir malam. Apakah posisi matahari $18^{\circ}$ mutlak untuk fajar astronomi? Definisi posisi matahari ditentukan berdasarkan kurva cahaya langit yang tentunya berdasharkan kondisi rata-rata atmosfer.

Dalam kondisi tertentu sangat mungkin fajar sudah muncul sebelum posisi matahari 18 di bawah ufuk, misalnya saat tebal atmosfer bertambah ketika aktifitas matahari meningkat atau saat kondisi komposisi udara tertentu antara lain kandungan debu yang tinggi sehingga cahaya matahari mampu dihamburkan oleh lapisan atmosfer yang lebih tinggi. Akibatnya, walau posisi matahari masih kurang dari $18^{\circ}$ di bawah ufuk, cahaya fajar sudah tampak. Para ulama' ahli hisab dahulu sudah merumuskan definisi fajar shadiq dengan kriteria beragam, berdasharkan pengamatan dahulu, berkisar $17^{\circ}-20^{\circ}$. Karena penentuan kriteria fajar tersebut merupakan produk ijtihadiyyah, perbedaan seperti itu dianggap wajar saja. Di Indonesia, ijtihad yang digunakan adalah posisi matahari 20 di bawah ufuk, dengan landasan dalil syar'i dan astronomis yang dianggap kuat.

Kriteria tersebut yang kini digunakan Kementerian Agama RI untuk jadwal shalat yang beredar di masyarakat. Kalau saat ini ada yang berpendapat bahwa waktu subuh yang tercantum di dalam jadwal shalat dianggap terlalu cepat. Hal ini disebabkan oleh dua hal: pertama, ada yang berpendapat fajar shadiq ditentukan dengan kriteria fajar astronomis pada posisi matahari $18^{\circ}$ di bawah ufuk, karena beberapa program jadwal shalat di internet menggunakan 
kriteria tersebut, dengan perbedaan sekitar 8 menit. Kedua, ada yang berpendapat fajar shadiq bukanlah fajar astronomis, karena seharusnya fajarnya lebih terang, dengan perbedaan sekitar 24 menit. Pendapat seperti itu wajar saja dalam interpretasi ijtihadiyyah.

Untuk mengetahui dan memahami pemikiran aliran salafi tentang penentuan awal waktu, ada beberapa buku, majalah, dan artikel dari website yang dapat dijadikan rujukan ${ }^{34}$. Makna fajar menurut bahasa menurut Ibn Mandzur adalah cahaya subuh, yaitu semburat merah di gelapnya malam karena sinar matahari. Ada dua fajar, yang pertama adalah meninggi (mustathil) seperti ekor serigala hitam (sirhan), dan yang kedua adalah yang melebar (memanjang, mustathir) disebut fajar shadiq, yaitu menyebar di ufuk, yang mengharamkan makan dan minum bagi orang yang berpuasa.

Subuh tidak masuk kecuali pada fajar shadiq ini. Dalam kitab Mukhtarus Sihah disebutkan, alfajr di akhir malam seperti syafaq (semburat mega merah) di awal malam." ${ }^{35}$ Dalam al-Qamus al-Muhith disebutkan, fajar adalah cahaya subuh, yaitu semburan sinar matahari yang merah" 36

Fajar dalam al-Qur`an dan Sunnah Allah berfirman :

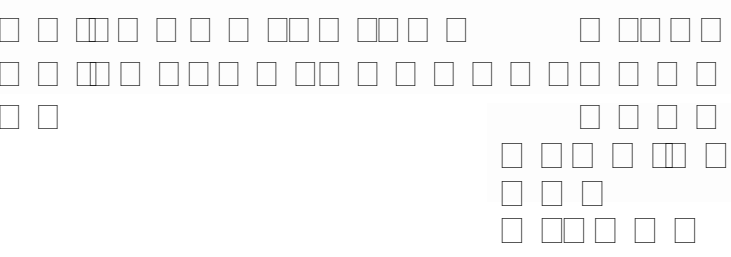

"Dan makan minumlah hingga terang bagimu benang putih dari benang hitam, Yaitu fajar. Kemudian sempurnakanlah puasa itu sampai (datang) malam." (QS. Al-Baqarah: 187)

Dari Salim bin Abdillah dari ayahnya, bahwa Rasulullah bersabda: "Sesungguhnya Bilal mengumandangkan adzan di waktu malam, makan dan minumlah hingga Ibn Ummi Maktum adzan.” Kemudian berkata, "Ia adalah laki-laki buta, ia tidak adzan hingga dikatakan kepadanya: Sudah subuh, sudah subuh.” (HR. al-Bukhari: 610).

\footnotetext{
34 Antara lain: Syekh Mamduh Farhan al-Buhairi dkk, Koreksi Awal Waktu Subuh, Malang, Pustaka Qiblati, 2010. Al-Daruri, Abu Abdurrahman Jalal, "Aushaful Fajran fil Kitab was Sunnah; wa fihi Tanbihun 'ala Adzanil Fajr al-Yaum", diterjemahkan oleh Abu Hudzaifah dengan judul Salah Kaprah Waktu Subuh. Solo : Qiblatuna. 2010. Majalah Qiblati edisi 8-11 tahun IV "Salah KaprahWaktu Shalat Subuh" bagian 1-4, edisi 2 tahun V "Dialog Qiblati dan Depag", Website www.qiblati.com, www.zamzamilmu.com, www.pakarfisika.com, dan situs-situs yang terkait dengan aliran salafi.

35 Qiblati edisi 8 Tahun IV, 34; al Buhairi, Koreks., h. 34.

36 Qiblati edisi 8 Tahun IV, 34; al Buhairi, Koreks., h. 34.
}

Al-Hakim dan al-Baihaqi meriwayatkan hadits dari Ibn Abbas bahwa Nabi saw bersabda, yang artinya :

"Fajar itu ada dua; fajar yang di dalamnya haram makanan serta dihalalkan shalat, kedua fajar yang di dalamnya halal makanan dan haram shalatsubuh.”

Dalam sebuah riwayat disebutkan,

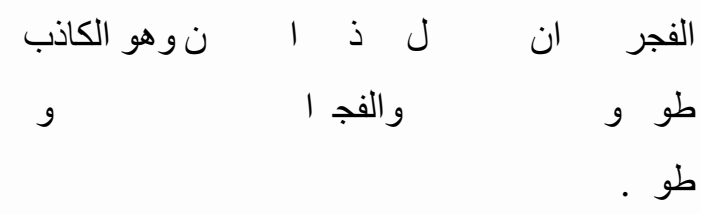

"Fajar ada dua, fajar yang disebut seperti ekor serigala adalah fajar kadzib yang memanjang vertikal dan tidak menyebar secara horizontal, yang kedua fajar yang melebar (horizontal) dan bukan vertikal."

Ibn Abbas mengatakan:

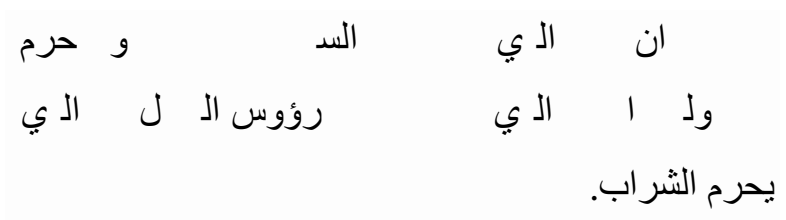

"Fajar ada dua, fajar yang mencuat ke langit tidak menghalalkan dan tidak pula mengharamkan

apapun, akan tetapi fajar yang jelas terlihat di puncak-puncak gunung, itulah yang mengharamkan minum.”

Ibn Qudama mengatakan, ringkasnya bahwa waktu subuh masuk dengan terbitnya fajar kedua, berdasarkan ijma' ulama'. Hadits-hadits tentang penentuan waktu shalat menunjukkan hal ini, yaitu sinar putih yang melebar di ufuk. Disebut fajar shadiq, karena ia benar memberitakan tentang subuh dan menjelaskannya kepada anda. Subuh itu adalah waktu yang menggabungkan sinar putih (terang) dengan semburat merah. Dari sini orang yang berkulit putih bercampur merah disebut ashbah. Sedangkan fajar pertama yaitu sinar terang yang memanjang ke atas dan tidak melebar (vertical), maka tidak ada sangkut pautnya dengan hukum syar'i, disebut fajar kadzib.

Ibn Hazm mengatakan, fajar pertama adalah meninggi ke atas seperti ekor serigala, setelah itu gelap lagi menyelimuti ufuk, tidak mengharamkan makan dan minum bagi orang yang puasa, belum masuk waktu shalat subuh. Ini tidak diperselisihkan oleh seorangpun dari umat ini. Yang kedua, adalah sinar 
terang yang melebar di langit di ufuk timur di tempat terbitnya matahari pada setiap masa. Ia berpindah dengan perpindahannya (matahari), ia merupakan permulaan cahaya subuh, dan semakin terang, barangkali dicampuri dengan semburat merah yang indah. Inilah yang menjelaskan masuknya waktu puasa, dan adzan shalat subuh. Adapun masuknya waktu shalat terjadi dengan semakin terangnya, maka ini tidak diperselisihkan oleh seorangpun.

Dari dalil-dalil tersebut, aliran salafi menyimpulkan bahwa fajar shadiq dapat diketahui dari sinar terang yang menyebar di langit. Sifat fajar shadiq dan fajar kadzib Ibn Jarir al-Thabari menjelaskan sifat atau karakter sinar terang dari fajar shadiq. Kesimpulan dari dalil tersebut memiliki arti :

"Sifat sinar subuh yang terang itu, ia menyebar dan meluas di langit, sinarnya (terangnya) dan cahayanya memenuhi dunia hingga memperlihatkan jalan-jalan menjadi jelas."

Syaikh Ibn Utsaimin mengatakan, para ulama' menyebutkan bahwa antara fajar kadzib dan fajar shadiq ada tiga perbedaan: (1) fajar kadzib mumtad (memanjang) tidak mu'taridh (menghadang); Mumtad maksudnya memanjang dari timur ke barat. Sedangkan fajar shadiq melebar dari utara ke selatan. (2) Fajar kadzib masih gelap, artinya cahaya fajar ini sebentar kemudian gelap lagi. Sedangkan fajar shadiq tidak dalam keadaan gelap, bahkan semakin lama semakin terang cahayanya (karena merupakan awal siang). (3) Fajar shadiq bersambung dengan ufuk, tidak ada kegelapan antara fajar ini dengan ufuk. Sedangkan fajar pertama, terputus dari ufuk, ada kegelapan antara fajar kadzib dan ufuk. Fajar pertama ini (kadzib) tidak berkaitan dengan hukum syariat apapun, tidak menjadi awal menahan diri dari makan minum ketika puasa, tidak pula awal masuknya waktu subuh. Hukum-hukum yang disebutkan ini berkaitan dengan fajar kedua, yakni fajar shadiq."

Warna fajar shadiq menurut al-Qur' an, Sunnah, pemahaman salaf halih dan data empiris: (1) putih membentang ${ }^{37}$ Nabi saw menafsiri Q.S. al-Baqarah ayat 187 dengan bersabda:

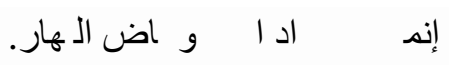

"Sesungguhnya ia adalah gelapnya malam dan putihnya (cahaya) siang” (HR. Bukhari dan Muslim dari Adiy ibn Hatim).
Jadi benang putih adalah putihnya siang bukan sekedar cahaya siang. Sifat dari putihnya cahaya siang tersebut adalah menyebar memenuhi langit, putihnya dan cahayanya memenuhi jalan-jalan. Syaikh Muhammad al-Amin mengatakan, maksudnya engkau merasakan pengaruh cahaya itu mulai ada di jalan-jalan, bukan maksudnya hari menjadi siang. Adapun cahaya putih yang menjulang atau meninggi di langit, maka bukan yang dimaksudkan oleh Allah dalam firman-Nya tadi (fajar kadzib). (2) merah membentang (putih kekuningan atau kemerah-merahan membentang) $)^{38}$. Rasulullah saw bersabda:

$$
\text { الفجر الا }
$$

"Bukanlah fajar itu yang meninggi di ufuk, akan tetapi yang membentang berwarna merah (fajar putih kemerah-merahan).” (HR. Ahmad, dari Qais ibn Thalq dari ayahnya. Hadis Hasan).

Menurut salafi, warna biru pada awal fajar shadiq disebutkan oleh penyair kondang zaman Abbasi (205284 H./821-898 M.) dalam bait syairnya:

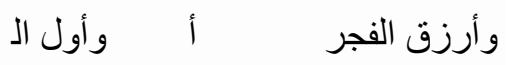

Birunya fajar datang sebelum putihnya, pertamanya hujan adalah tetesan kemudian dicurahkan".

Penyair itu melihat sebelum terbitnya cahaya putih, ada cahaya biru di langit di timur di musim hujan. Hal itu terjadi di gurun pasir di negeri Syinqth. Cahaya biru itu membentang ke kanan dan kiri, tidak ada gelap setelahnya. Hal ini sebagaimana dijelaskan oleh Syaikh al-Darudi. Cahaya biru dari awal fajar shadiq ini juga dijelaskan oleh Syaikh Abdul Malik al-Kulaib bahwa dalam pengamatannya terhadap fajar di al-Hawiyyah, dia melihat pertama kali sesuatu yang menyerupai warna biru kemudian merah. Hal itu terjadi di musim hujan. Warna biru itu memanjang membentang ke utara dan selatan. Dia menjadikan sudut derajat matahari untuk awal fajar dari situ. Pada kesimpulannya tidak ada pertentangan antara putih dan merah dalam sifat awal fajar shadiq.

Awal fajar shadiq yang tampak terang terkadang berwarna putih, merah, putih kemerahan, atau bahkan ada warna birunya. Hal ini dapat dibenarkan oleh pengamatan dan foto-foto fajar. Yang bertanggung jawab menentukan waktu fajar menurut Salafi adalah ulama'. Sedangkan penentuan jadwal itu peran ahli falak. Ulama' syariat yang menentukan waktu

38 Qiblati edisi 8 Tahun IV, 34; al Buhairi, Koreks., h. 175-189. 
fajar, kemudian atas ketetapan ini bertolaklah peran ahli falak. Mereka yang menentukan sudut elevasi matahari, waktu syuruq, melakukan perhitungan detil. $^{39}$

Namun, semenjak masa pembentukan penanggalan Islam, ahlifalak lebih mengutamakan untuk dirinya dalam penetapan waktu-waktu shalat. Mereka tidak memberikan kesempatan kepada ulama' syariat untuk melakukan tugas apapun berkenaan dengan penentuan waktu shalat ini. Padahal sebenarnya ulama'lah yang lebih berhak dari pada mereka untuk menentukan waktu shalat ini, karena shalat itu berhubungan dengan agama. Dan umat Islam diperintahkan untuk mengambil agama mereka dari para ulama', bukan dari ahli falak. Ulama' syariat telah melalaikan tugas ini karena dua alasan. ${ }^{40}$ Pertama; rasa penerimaan terhadap detil penanggalan, di mana mereka melihat dalam waktuwaktu shalat yang indrawi (seperti dzuhur dan ashar) sudah benar, sehingga mereka mengira bahwa untuk shalat-shalat yang lain penanggalan tersebut juga benar. Mereka percaya terhadap ilmu para ahli falak. Padahal sebenarnya ahli falak di dunia Islam telah gagal total dalam menentukan bukan hanya waktu fajar tetapi juga maghrib dan isya'. Kedua, kesibukan ulama' dalam bidang ilmu dan dakwah, pengajaran dan ceramah, mereka meninggalkan sisi penentuan waktu shalat dan memberikannya kepada ahli falak. Karena itulah, aliran Salafi hendak mengembalikan kehormatan ilmu dan ulama'.

\section{Pembahasan}

Akar permasalahan dari penentuan awal waktu shalat subuh adalah berangkat dari sudut pandang yang berbeda, yaitu versi astronomi (sains) dan versi syar'i. BHR Depag menggunakan landasan astronomi dalam penentuan awal waktu subuh. Sedangkan Salafi menggunakan landasan syar'i. Dilihat dari komposisi susunan pengurus BHR Depag, tidak sedikit latar belakang ahli/pakar falak yang mendalami ilmu syar'i. Karena mayoritas ahli falak yang berkecimpung di BHR Depag itu berasal dari latar belakang astronomi, maka bisa dikatakan BHR Depag mewakili astronomi dalam penentuan awal waktu shalat ini. Selain itu, dalil-dalil yang digunakan dalam penentuan awal waktu shalat ini tidak hanya berdasarkan dalil-dalil astronomi saja, tetapi ada dalil-dalil syar'inya (alQur'an, Sunnah, ahli falak, dan pakar astronomi).

Sedangkan kalangan Salafi menganggap diri mereka sebagai kalangan syar'i dalam masalah ini,

39 Qiblati edisi 8 Tahun IV, 34; al Buhairi, Koreks., h. 67.

40 Qiblati edisi 8 Tahun IV, 34; al Buhairi, Koreks., h. 68. karena sudut pandang yang digunakan pertama kali dalam masalah ini adalah penentuan awal waktu shalat menurut al-Qur' an, Sunnah, dan salaf shalih.

Untuk memudahkan dan memfokuskan analisis terhadap permasalahan ini, peneliti menemukan poinpoin permasalahan sebagai berikut: (1) pengertian fajar dan pembagiannya menurut syar'i dan astronomi menurut BHR Depag, fajar (morning twilight) menurut syara' itu ada dua, yaitu fajar shadiq dan fajar kadzib. Fajar shadiq adalah hamburan cahaya matahari oleh partikel-partikel di udara yang melingkupi bumi. Dalam bahasa al-Qur'an fenomena itu diibaratkan dengan ungkapan "terang bagimu benang putih dari benang hitam”, yaitu peralihan dari gelap malam (hitam) menuju munculnya cahaya (putih). Dalam bahasa fisika hitam bermakna tidak ada cahaya yang dipancarkan, dan putih bermakna ada cahaya yang dipancarkan. Karena sumber cahaya itu dari matahari dan penghamburnya adalah udara, maka cahaya fajar melintang di sepanjang ufuk (horison, kaki langit). Itu pertanda akhir malam, menjelang matahari terbit. Semakin matahari mendekati ufuk, semakin terang fajar shadiq.

Jadi batasan yang bisa digunakan adalah jarak matahari di bawah ufuk. Fajar kidzib memang bukan fajar dalam pemahaman umum, yang secara astronomi disebut cahaya zodiak. Cahaya zodiak disebabkan oleh hamburan cahaya matahari oleh debu-debu antar planet yang tersebar di bidang ekliptika yang tampak di langit melintasi rangkaian zodiak (rangkaian rasi bintang yang tampaknya dilalui matahari). Oleh karenanya fajar kidzib tampak menjulur ke atas seperti ekor serigala, yang arahnya sesuai dengan arah ekliptika. Fajar kidzib muncul sebelum fajar shadiq ketika malam masih gelap.

Sedangkan menurut pembagian astronomis, fajar dibagi tiga, yaitu fajar astronomi, fajar nautika, dan fajar sipil. Fajar astronomi didefinisikan sebagai akhir malam, ketika cahaya bintang mulai meredup karena mulai munculnya hamburan cahaya matahari. Biasanya didefinisikan berdasharkan kurva cahaya, fajar astronomi ketika matahari berada sekitar $18^{\circ}$ di bawah ufuk. Fajar nautika adalah fajar yang menampakkan ufuk bagi para pelaut, pada saat matahari berada di sekitar $12^{\circ}$ di bawah ufuk. Fajar sipil adalah fajar yang mulai menampakkan benda benda disekitar kita, pada saat matahari berada sekitar $6^{\circ}$. Sedangkan menurut Salafi, fajar itu ada dua, baik secara syar'i maupun astronomi, yaitu fajar shadiq dan fajar kadzib.

Mengenai pembagian fajar secara syar'i, keduanya bersepakat dan tidak mempermasalahkan. Namun, 
pembagian fajar secara astronomi, Salafi berpendapat bahwa hal itu merupakan perkara bid'ah. Bahkan fajar astronomi yang menurut BHR Depag dianggap sebagai fajar shadiq, Salafi menganggapnya sebagai fajar kadzib. Lebih lanjut, Salafi mendefinisikan fajar shadiq sebagai semburat merah di gelapnya malam karena sinar matahari, menyebar di ufuk secara horizontal yang mengharamkan makan dan minum bagi orang yang berpuasa. Sedangkan fajar kadzib adalah yang menyebar di ufuk secara vertikal.

Interpretasi Dalil Al-Qur'an dan Sunnah Hadis Abu Mas'ud al Anshari dan Aisyah.

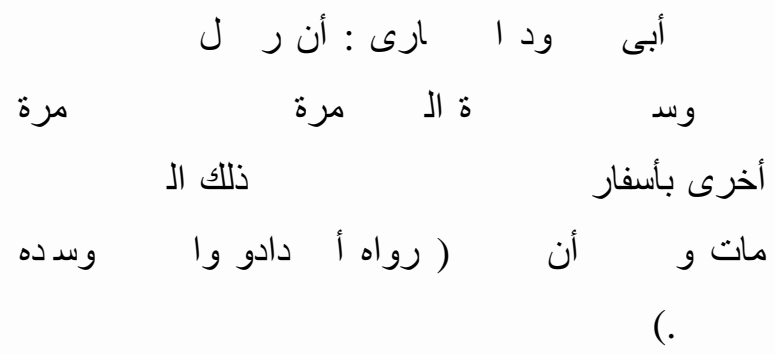

"Rasulullah saw shalat subuh saat kelam pada akhir malam, kemudian pada kesempatan lain ketika hari mulai terang. Setelah itu shalat tetap dilakukan pada waktu gelap sampai beliau wafat, tidak pernah lagi pada waktu mulai terang." (HR Abu Dawud dan Baihaqi dengan sanad yang sahih).

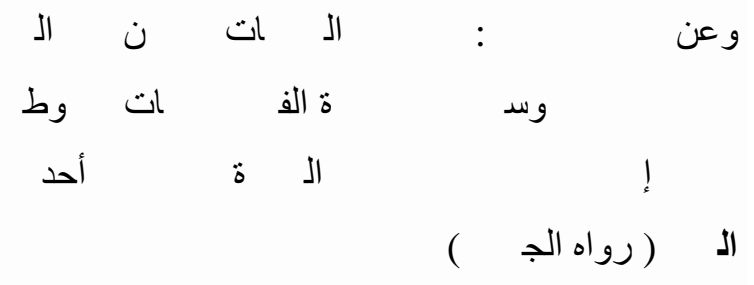

Dari Aisyah,"Perempuan-perempuan mukmin ikut melakukan shalat fajar (subuh) bersama Nabi saw dengan menyelubungi badan mereka dengan kain. Setelah shalat mereka kembali ke rumah tanpa dikenal siapapun karena masih gelap." (H.R. Jama'ah).

Dari dua hadis di tersebut, yang menjadi persoalan adalah pengertian الغلس . Menurut BHR Depag, kata al-ghalas artinya kelam pada akhir malam, masih gelap. Jadi Nabi Muhammad saw melaksanakan shalat subuh pada waktu akhir malam di mana kondisinya masih gelap. Sedangkan menurut Salafi, pengertian yang benar dari kata al-ghalas adalah percampuran kegelapan malam dengan cahaya subuh. Disebutkan dalam Lisanul Arab, al-ghalas adalah awal subuh hingga menyebar di ufuk. ${ }^{41}$

41 Qiblati edisi 8 Tahun IV, 34; al Buhairi, Koreks., h. 47.
Maka al-ghalas artinya kegelapan di waktu subuh. Mereka kemudian membedakan pengertian ghalas dengan 'atamah, yaitu kegelapan di waktu malam. Posisi matahari awal waktu subuh (kemunculan fajar shadiq) menurut BHR Depag, posisi matahari pada awal waktu shalat subuh di mana fajar shadiq itu muncul adalah $-20^{\circ}$ di bawah ufuk atau $110^{\circ}$ dari jarak zenith matahari. Hal ini didasarkan pada pendapat H. Saadoeddin Jambek dan Drs. Abd. Rachim. Beliau berijtihad dengan menambahkan $2^{\circ}$ karena kemampuan mata pada pagi hari berbeda kepekaannya.

Sedangkan Salafi berpendapat bahwa posisi matahari saat munculnya fajar shadiq adalah $-15^{\circ}$ di bawah ufuk. Hal ini didasarkan pada penanggalan ISNA (Islamic Society of North America). Mereka berargumen bahwa sebelumnya ketua panitia penanggalan ISNA, yaitu Dr. Syaukat, menekankan bahwa sudut yang benar untuk waktu fajar adalah $13,5^{\circ}-14$, akan tetapi ia memilih sudut $15^{\circ}$ untuk kehati-hatian.

Kesimpulan ini dicapai setelah penelitian yang lama dengan mengamati mega dan fajar shadiq di tempat-tempat yang berbeda; Amerika, Pakistan, Inggris, Karibia, Australia, dan New Zeland. Setelah itu Dr. Syaukat menghitung setiap observasi dan menemukan hasil yang hampir sama dengan sudut $13,5^{\circ}$ hingga $14^{\circ}$. Setelah itu ia menambahkan kehatihatian (little factor safety), yaitu 1 hingga 1,5 , agar menghasilkan sudut $15^{\circ}$ sebagai solusi yang diandalkan untuk penanggalan di setiap tempat. ISNA kemudian menggunakan sudut $15^{\circ}$ ini untuk shalat fajar dan isya', ${ }^{42}$

Dari ketiga poin permasalahan yang dipaparkan, analisis yang disampaikan sebagai berikut: (1) pengertian fajar dan pembagiannya menurut syar'i dan astronom. Sebuah definisi akan lebih bermakna apabila digambarkan secara jami' dan mani'. Definisi yang jami' yaitu sebuah kata tersebut yang mencakup gambaran dari kata tersebut secara komprehensif dan universal. Sedangkan mani' adalah kata tersebut membatasi ambiguitas kata itu. (2) interpretasi dalil al-Qur' an dan Sunnah. Dalam memahami teks agama (al-Qur'an dan Sunnah), seseorang harus memahami terdahulu asbab al-nuzul dan asbab al-wurud dari teks teks tersebut.

Asbab al-nuzul dan asbab al-wurud adalah alasan teks-teks tersebut diturunkan/diwahyukan. Artinya Allah tidak akan menurunkan wahyu ayat dari al-

42 Qiblati edisi 8 Tahun IV, 34; al Buhairi, Koreks., h. 20 
Qur'an dan Sunnah tanpa adanya sebab. Selanjutnya melalui kedua sebab di tersebut, seorang penafsir menafsirkan atau memberikan interpretasi pada teksteks itu. Dengan memperhatikan siapa yang dihadapi oleh Nabi Muhammad, di mana dan dalam kondisi seperti apa, pada waktu teks ayat dan hadis tersebut diturunkan. Maksudnya, dengan memperhatikan apa, siapa, kapan, di mana, dan bagaimana situasi dan kondisi teks-teks agama itu diturunkan. (3) posisi matahari awal waktu subuh (kemunculan fajar shadiq) Penentuan awal shalat itu sangat dipengaruhi oleh peredaran matahari. Pengamatan fajar shadiq sebagai tanda awal waktu subuh sangat dipengaruhi oleh refraksi/pembiasan matahari, kelembaban udara dan kerendahan ufuk.

Dari semua yang telah dipaparkan, dapat diambil beberapa kesimpulan sebagai berikut: (1) Perbedaan pendapat di antara umat merupakan sebuah rahmat yang telah diberikan Allah kepada hamba-hambaNya. (2) Ijtihad seseorang tidak dapat digugurkan dengan ijtihad orang lain. (3) Perkara bid'ah itu boleh diakses selama tidak bertentangan dengan syara'. (4) Menjaga tradisi kuno yang masih relevan dan mengadopsi tradisi baru yang patut.

Perbandingan penentuan awal shalat subuh menurut Badan Hisab Rukyat Departemen Agama dan Aliran Salafi berdasarkan paparan dan analisis data yang telah digambarkan di atas, maka pada bagian ini dipaparkan juga beberapa perbedaan secara ringkas sebagai berikut: Perbedaan perbedaan yang berkaitan dengan dalil syar'i dan astronomi. Jenis BHR Aliran Salafi (Tabel I)

\section{Kesimpulan Dan Saran \\ Kesimpulan}

Setelah melakukan analisis terhadap data, dapat disimpulkan bahwa pandangan BHR Depag dan aliran Salafi tentang penentuan awal waktu shalat subuh adalah sebagai berikut: (1) Penentuan awal waktu shalat subuh; (a) Menurut BHR Kementerian Agama, penentuan awal waktu subuh ini merupakan masalah ijtihadiyah; (b) Menurut Aliran Salafi, penentuan awal waktu subuh ini merupakan masalah ibadah yang penting dan sakral, sehingga harus ada perhatian yang lebih serius. (2) Perbedaan penentuan awal waktu subuh menurut kedua organisasi; (a) Interpretasi terhadap ayat al-Qur'an dan hadis Nabi saw khususnya yang berkaitan dengan fajar shadiq; (b) Perspektif yang digunakan juga oleh kedua organisasi itu, BHR Depag berangkat dari perspektif astronomi sedangkan aliran Salafi menggunakan perspektif Syar'i. (c) Pengertian astronomical twilight yang berbeda; BHR Depag menganggap astronomical twilight sebagai fajar shadiq, sedangkan Salafi menganggapnya sebagai fajar kadzib.

\section{Saran}

Diharapkan kepada semua pihak yang terkait dalam penentuan waktu-waktu shalat seperti aliran Salafi, Badan Hisab Rukyat Kementerian Agama,

Tabel I

\begin{tabular}{|lll|}
\multicolumn{1}{|c}{ JENIS } & \multicolumn{1}{c|}{ BHR } & \\
KEMENTERIAN AGAMA & \multicolumn{1}{c|}{ SALAFI } \\
Makna al-Ghalas & Kelam pada Akhir malam & Kegelapan malam di waktu subuh \\
Penentuan awal waktu shalat & Masalah ijtihadiyyah & $\begin{array}{l}\text { Ketetapan al-Qur' an dan } \\
\text { Sunnah }\end{array}$ \\
Astronomical twilight & Fajar shadiq dengan tambahan $2^{\circ}$ & $\begin{array}{l}\text { Fajar kadzib } \\
\text { Pesisi }\end{array}$ \\
Posisi matahari awal waktu subuh & $-20^{\circ}$ di bawah ufuk & $15^{\circ}$ di bawah ufuk \\
Sistem penanggalan & The British Royal & $\begin{array}{l}\text { ISNA; (PerhimpunanMasyarakat } \\
\text { Muslim Amerika Utara) }\end{array}$ \\
Pembagian fajar & $\begin{array}{l}\text { fajar astronomi } \\
\text { fajar nautika } \\
\text { fajar sipil }\end{array}$ & $\begin{array}{l}\text { Fajar shadiq } \\
\text { fajar kadzib }\end{array}$
\end{tabular}


para ahli falak dan astronomi, dan penuntut ilmu di Fakultas Syari'ah untuk melanjutkan penelitian dan observasi tentang waktu-waktu shalat, khususnya

\section{Daftar Pustaka}

Buku

Al-Qur'an al-Karim.

Abdullah, M. Amin, dkk. 2006. Metodologi Penelitian Agama: Pendekatan Multidisipliner. Yogyakarta: Kurnia Kalam Semesta.

Arikunto, Suharsimi. 2006. Prosedur Penelitian : Suatu Pendekatan Praktik.Jakarta : PT Rineka Cipta.

Al-'Asqalaniy, Al-Hafidh bin Hajar. t.t. Bulughul alMaram min Adillah al-Ahkam. Syirkah Al-Nur Asia

Azzam, Abdul Aziz Muhammad dan Abdul Wahhab Sayyed Hawwas. 2009. Fiqih Ibadah. Jakarta: Amzah

Al-Banjari, Syekh Muhammad Arsyad. 2005. "Sabilul Muhtadin". Terjemahan oleh Drs. H.M. Asywadie Syukur, Lc., Sabilul Muhtadin. Surabaya: PT Bina Ilmu.

Bisri, Cik Hasan. 2004. Pilar-pilar Hukum Islam dan Pranata Sosial. Jakarta: PT. RajaGrafindo Persada.

Al-Buhairi, Syekh Mamduh Farhan dkk. 2010. Koreksi Awal Waktu Subuh, Malang: Pustaka Qiblati.

Al-Daruri, Abu Abdurrahman Jalal. 2010. ”Aushaful Fajran fil Kitab was Sunnah; wa fihi Tanbihun 'ala Adzanil Fajr al-Yaum”. Terjemahan oleh Abu Hudzaifah dengan judul Salah Kaprah Waktu Subuh. Solo : Qiblatuna.

Departemen Agama RI. 1994. Pedoman Penentuan Waktu Shalat Sepanjang Masa, Jakarta.

Departemen Agama RI. 1989. al-Qur'an dan Terjemahnya: Juz 1 - Juz 30. Jakarta: Yayasan Penyelenggara Penterjemah Al-Qur'an.

Fakultas Syari'ah UIN Malang, Buku Pedoman Penulisan Karya Ilmiah, Malang: Fakultas Syari'ah Universitas Islam Negeri (UIN) Malang, t.th.

Hasan, Iqbal. 2002. Pokok-Pokok Materi Metodologi Penelitian dan Aplikasinya. Jakarta : Ghalia Indonesia.

Al-Husaini, Imam Taqiyuddin Abi Bakar Bin Muhammad. 2007. Kifayatul Akhyar fi Halli Gayatul Ikhtisar. Terjemahan oleh KH. Syarifuddin Anwar dan K.H. Mishbah Musthafa tentang fajar shadiq. Hal ini dibutuhkan dalam rangka mencari validitas dan keakuratan sebuah penelitian.

dengan judul Kifayatul Akhyar (Kelengkapan Orang Saleh). Surabaya : CV Bina Iman. Jamhari dan Jajang Jahroni. 2004. Gerakan Salafi Radikal di Indonesia, Jakarta: PT RajaGrafindo Persada

Maskufa. 2009. Ilmu Falak. Jakarta: Gaung Persada Press.

Moleong, Lexy, J. 1999. Metode Penelitian Kualitatif. Yogyakarta: Liberty.

Moleong, Lexy, J. 2007. Metodologi Penelitian Kualitatif. Bandung : PT Remaja Rosdakarya.

Murtadho, Moh. 2008. Ilmu Falak Praktis. Malang: UIN-Malang Press.

Murodi. 1999 Melacak Asal Usul Gerakan Paderi Di Sumatra Barat. Ciputat: PT Logos Wacana Ilmu

Al-Nawawi, Imam Abu Zakariya bin Yahya bin Syaraf al Dimasyqi. 2007.

RaudhahalThalibin diterjemahkanoleh H. Muhyiddin Mas Rida dkk.. Jakarta : Pustaka Azzam.

Raudhah al Thalibin .tt. Riyadlush al-Shalihin, Surabaya: Dar al-Nasyr al-Mishriyyah

Nazir, Moh. 1988. Metode Penelitian. Jakarta: Ghalia Indonesia.

Oliver, Haneef James. 2009. "The Wahhaby Myth", diterjemahkan oleh Ummu Abdillah al Butoniyah dengan judul Menyikap Mitos Wahhabi: Menepis pemahaman keliru dan hubungan fiktif dengan bin laden, Maktabah

Raudhah al-Muhibbin-e-book online.

Rahman, Afzalur \& Murtadha Muthahhari. 2006. Energi salat : Gali Makna, Genggam Ketenangan Jiwa.

Saifullah (2006) Metodologi Penelitian. Malang : Fakultas Syari'ah UIN Malang.

Soekanto, Soejono dan Sri Mahmudji. 2003. Penelitian Hukum Normatif: Suatu Tinjauan Khusus. Jakarta: Raja Grafindo Persada.

Al-Suhaimi, Fawwaz bin Hulayil bin Rabah. 2003. Manhaj Dakwah Salafiyah, Yogyakarta: Pustaka al Haura'.

Al-Syekh al-Imam al-Alim al-Fadhil Abu Abdul Mu'thi Muhammad al-Nawawi al-Jawi. tt. Syarh Kasyifah al-Saja ala Safinah al-Naja fi Ushul 
134 Jurisdictie, Jurnal Hukum dan Syariah, Volume 2, Nomor 2, Desember 2011, hlm 120-134

al-Din wa al-Fiqh. Surabaya: al-Hidayah.

Surat Kabar

Jawa Pos, (24 Maret 2010). Azan Subuh di Indonesia Terlalu Pagi

Jawa Pos, (26 Maret 2010). Mahmudi Asyari. Salat Subuh "Terlalu” Pagi.

\section{Majalah}

Qiblati edisi 8 tahun IV

Qiblati edisi 9 tahun IV
Qiblati edisi 10 tahun IV Qiblati edisi 11 tahun IV Qiblati edisi 2 tahun V

\section{Website}

Arkanuddin, Mutoha, Menentukan Waktu Shalat, (Lembaga Pengkajian Dan Pengembangn Ilmu Falak (LP2IF) Rukzatul Hilal Indonesi (RHI)) diakses tanggal 18 April 2010 